\title{
Genetic diversity of Brazil-nut populations naturally occurring in the municipality of Alta Floresta, MT, Brazil
}

\author{
F.S. Vieira ${ }^{1}$, A.A. Rossi $^{1}$, G.F. Pena ${ }^{1}$, A.V. Tiago ${ }^{1}$, K.É.M. Zortéa ${ }^{1}$, \\ K.F.M. Schmitt ${ }^{1}$, L.D. Giustina ${ }^{1}$, F.S. Rossi ${ }^{1}$ and P.H.A.D. Santos ${ }^{2}$ \\ ${ }^{1}$ Universidade do Estado de Mato Grosso, Faculdade de Ciências Biológicas \\ e Agrárias, Alta Floresta, MT, Brasil \\ ${ }^{2}$ Universidade Estadual do Norte Fluminense Darcy Ribeiro, Centro de \\ Ciências e Tecnologias Agropecuárias, Campos dos Goytacazes, RJ, Brasil \\ Corresponding author: G.F. Pena \\ E-mail: penabio2@gmail.com
}

Genet. Mol. Res. 18 (2): gmr18174

Received October 10, 2018

Accepted March 28, 2019

Published April 30, 2019

DOI http://dx.doi.org/10.4238/gmr18174

\begin{abstract}
Brazil nut is a native Amazon species of high commercial value classified as vulnerable in terms of extinction risk due to marked illegal-burning activity and agricultural-frontier expansion processes occurring in the region. This study was undertaken to analyze the genetic diversity within and between two natural Brazil-nut populations occurring spontaneously in the Southern Amazon region spaced $50 \mathrm{~km}$ apart, both of which were located in the municipality of Alta Floresta, northern Mato Grosso state, Brazil. These are rural areas and samples were from native forest patches. Leaf samples were collected from 86 plants from distinct areas; 36 were from population AGRO (Agrocondor II Farm,

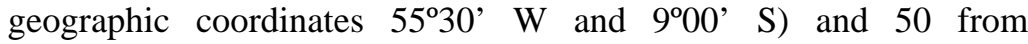
population CAR (Carolina Farm, geographic coordinates $57^{\circ} 00^{\prime} \mathrm{W}$ and $11^{\circ} 00^{\prime} \mathrm{S}$ ). A molecular-diversity study was conducted using 11 microsatellite loci developed for the species. To determine the level of genetic diversity between and within subpopulations, we applied principal coordinate analysis, analysis of molecular variance, observed and expected heterozygosity, polymorphic information
\end{abstract}


content (PIC), UPGMA-based clustering, and Bayesian inference structuring. Seventy alleles were found with the SSR markers, with an average PIC of 0.72. Average Ho and He were 0.43 and 0.82 , respectively. AMOVA revealed that $81 \%$ of the variability is within populations, as found in other studies of Brazil-nut in the states of Pará, Acre and Amazonas. The dendrogram obtained by the UPGMA method and the clustering provided by Bayesian inference resulted in two and four groups formed, respectively. All 36 individuals of the AGRO population were allocated in Group I, and the 50 individuals of population CAR were allocated in Groups II, III, and IV. The two subpopulations have sufficient genetic variability for the composition of an in situ germplasm bank that can be used in breeding programs and in programs for the conservation of the species.

Key words: Conservation; Genetic resources; Bertholletia excels; Molecular diversity

\section{INTRODUCTION}

Brazil nut (Bertholletia excelsa), a member of the Family Lecythidaceae, is a largesized tree considered one of the most valuable native species of the upland (non-flooding) Amazon forest (Costa et al., 2009). It produces edible seeds that constitute one of the most actively marketed non-timber forest products of the Amazon (Albuquerque et al., 2015). This species is part of the culture of traditional Amazon populations because of the broad use of its products and by-products for several generations as a food source in its natural state or industrialized (Cunha and Dantas, 1997). It is also used as raw material in the production of crafts, cosmetics, and drugs (Souza, 2006). Although its extraction and felling have been forbidden by a federal law since 1994, natural populations of the species have progressively declined. Despite its sociocultural importance and economic potential, Brazil nut is still classified as vulnerable, according to the Red List of Threatened Species (IUCN, 2017).

Because tree species are long-lived organisms and the fragmentation of Brazilian forests is a relatively recent phenomenon, the effects of forest fragmentation on genetic diversity, inbreeding, and spatial genetic structures are difficult to be directly observed in samples of reproductive individuals (Aguilar et al., 2010; Sebbenn et al., 2010).

The study of genetic distribution within and between populations; the intraspecific diversity levels; and understanding how this variability is structured in space are important for outlining strategies for the genetic conservation, sustainable management, and breeding of a species (Kageyama et al., 2003; Rossi et al., 2009; Rivas et al., 2013).

Molecular markers provide an approach at individual level, which makes them much more efficient for determining genetic variability inasmuch as they analyze variations from the genetic material, with zero influence of environmental factors. Additionally, they can be used at any stage of the plant development (Yanaka et al., 2005; Kamada et al., 2009). Molecular markers based on the amplification of microsatellites, SSR (Simple Sequence Repeats), comprise a class of repetitive DNA composed of small sequences of one to six repeated adjacent nucleotides scattered across the genome (Caixeta et al., 2013). 
At present, microsatellites are one of the most robust methods for genetic studies of populations (Selkoe and Toonen, 2006), mainly because they are codominant, abundant in the genome, highly reproducible and polymorphic, and widely distributed in the genome (Saha et al., 2006). They can be used to determine the degree of relatedness of individuals and or groups of the same species; for ancestry analysis (paternity tests); for forensic analysis; as a tool to evaluate the inbreeding levels of a population; and to evaluate the special genetic structure and the genetic diversity of native and cultivated species (Blouin et al., 1996; Isagi et al., 2004; Arbeláez-Cortes et al., 2007; Dardengo et al., 2016).

The aim of this study was to analyze the genetic diversity within and between natural subpopulations of $B$. excels occurring spontaneously in northern Mato Grosso State, Brazil.

\section{MATERIAL AND METHODS}

\section{Collection sites and plant material}

Leaf-sample of adult individuals, in the reproductive phase, was collected place in two areas in Southern Amazon spaced $50 \mathrm{~km}$ apart, both of which were located in the municipality of Alta Floresta - MT, Brazil. By means of extractivism, this region has the Brazil-nut as an important income source for the local economy. Eighty-six plants were sampled from two B. excelsa subpopulations: 36 from population AGRO (Agrocondor II Farm, geographic coordinates $55^{\circ} 30^{\prime} \mathrm{W}$ and $9^{\circ} 00^{\prime} \mathrm{S}$ ) and 50 from population CAR (Carolina Farm, geographic coordinates $57^{\circ} 00^{\prime} \mathrm{W}$ and $11^{\circ} 00^{\prime} \mathrm{S}$ ). The Agrocondor II farm (AGRO) has approximately 1,283 hectares and the Carolina farm (CAR), approximately 17,144 hectares; both are private properties that maintain legal reserve areas where natural extractivism is developed and, in contiguous areas, there are agricultural and cattle raising activities.

Sampling was performed at random, using the largest space possible between individuals of each subpopulation. Leaf material was collected using a manual slingshot from each sampled individual, which was then identified and stored in silica gel still on the field and transported to the Laboratory of Plant Genetics and Molecular Biology at the State University of Mato Grosso State, Alta Floresta Campus.

\section{Extraction of genomic DNA and genotyping of microsatellite loci}

The total genomic DNA was extracted from approximately $100 \mathrm{mg}$ of leaves by following the protocol described by Doyle and Doyle (1990), with modifications: polyvinylpyrrolidone (PVP) and $\beta$-mercaptoethanol concentrations in the extraction buffer increased from 1 to $2 \%$ and 0.2 to $3 \%$, respectively, and incubation time at $65{ }^{\circ} \mathrm{C}$ reduced from $60^{\prime}$ to $05^{\prime}$. The quality and concentration of DNA were determined by $1 \%$ agarose gel electrophoresis, revealed in ethidium bromide, using a $\lambda$-DNA molecular weight marker of 50 and $100 \mathrm{ng} . \mu \mathrm{L}^{-1}$. Based on this quantification, DNA samples were diluted to the concentration of $10 \mathrm{ng} \cdot \mu \mathrm{L}^{-1}$.

Microsatellite regions were amplified via PCR (polymerase-chain reaction) using 11 SSR primers developed by Rafalski et al. (1996), for B. excelsa. Each PCR reaction was run considering a total volume of $13 \mu \mathrm{L}$, using $10 \mathrm{mM}$ Tris- $\mathrm{HCl}(\mathrm{pH} 8.3), 50 \mathrm{mM} \mathrm{KCl}, 2.5$ 
$\mathrm{mM} \mathrm{MgCl} 2,0.2 \mathrm{mM} \mathrm{dNTP}, 1 \mathrm{mM}$ primer, $0.5 \mathrm{U}$ Taq DNA polymerase $(5 \mathrm{U} / \mu \mathrm{L}), 10 \mathrm{ng}$ DNA template, and autoclaved distilled water. Amplifications were run on a MJ 96 thermocycler (Biocycler) using the amplification program described by Reis et al. (2009), as follows: initial denaturation at $94{ }^{\circ} \mathrm{C}$ for $5 \mathrm{~min} ; 30$ cycles at $94{ }^{\circ} \mathrm{C}$ for $45 \mathrm{~s} ; 44$ at $60{ }^{\circ} \mathrm{C}$ (according to the primer used) for $45 \mathrm{~s}$ and $72{ }^{\circ} \mathrm{C}$ for $30 \mathrm{~min}$; and a final extension of $72{ }^{\circ} \mathrm{C}$ for $7 \mathrm{~min}$. Amplification products were separated by high-resolution 3\% agarose gel electrophoresis $(\mathrm{m} / \mathrm{v})$ with $1 \mathrm{X}$ TBE running buffer at an approximate voltage of $100 \mathrm{~V}$, for about $4 \mathrm{~h}$. The gel was stained with ethidium bromide $\left(0.6 \mathrm{ng} \cdot \mathrm{mL}^{-1}\right)$. A 100 -pb DNA ladder (Invitrogen) was used to compare the sizes of amplified fragments. Gels were documented using a UVB-LTB transilluminator (Loccus) and a digital camera (Sony).

\section{Data analysis}

The SSR fragments were evaluated according to their size (pb) using GelQuant Pro software (Omictools) and used to generate a numerical matrix based on the codominant pattern of the markers, from which the genetic distance between the evaluated genotypes was calculated. The matrix data were analyzed using GenAlEx 6.5 software (Peakall and Smouse, 2012) to obtain the principal coordinates analysis (PCoA) and molecular variance (AMOVA), the latter of which was employed to infer about the genetic structure of the populations via full decomposition into components between and within populations.

PowerMarker V.3.25 software (Liu and Mouse, 2005) was used to determine allele frequency, genetic diversity, observed and expected heterozygosity, and PIC. The matrix of Nei's (1973) genetic distance values between individuals, generated by PowerMarker V.3.25 software, was imported into MEGA 6.5 software (Kumar et al., 2004) to construct the dendrogram based on the Unweighted Pair Group Method Using Arithmetic Averages (UPGMA); i.e., the average of distances between all pairs of genotypes was used to form each group. Structure software (Pritchard et al., 2000), based on Bayesian statistics, was used to infer about the genetic structuring of the studied genotypes. Twenty runs were performed for each k value, with 200,000 burn-ins and 500,000 Markov Chain Monte Carlo simulations (MCMC). To define most suitable number of groups $(\mathrm{k})$, we adopted the criteria proposed by Pritchard and Wen (2004) and Evanno et al. (2005), whose individual structuring results based on allele frequencies were subsequently visualized using Structure Harvester software (Earl et al., 2012).

\section{RESULTS}

The 11 microsatellite loci used for the genotyping of the $86 \mathrm{~B}$. excelsa individuals revealed a total of 70 alleles, with an average of 6.36 alleles per loci. The maximum and minimum numbers of alleles obtained per primer were 9 (Bex22 and Bex33) and 4 (Bex12), respectively.

The polymorphic information content ranged from 0.67 (Bex01) to 0.80 (Bex22), averaging 0.72 . Average observed heterozygosity was 0.43 , with a maximum value of 0.68 for primer Bex06 and a minimum of 0.16 for primer Bex12. Expected heterozygosity averaged 0.82 and was always above the observed value for all markers (Table 1). 
Table 1. Number of alleles (Na), genetic diversity (GD), expected heterozygosity (He), observed heterozygosity (Ho), and polymorphic information content (PIC) for the 11 SSR primers based on the amplification of 86 Bertholletia excelsa individuals of the two populations sampled in the municipality of Alta Floresta - MT, Brazil.

\begin{tabular}{llllll}
\hline Primer & Na & GD & He & Ho & PIC \\
\hline Bex01 & 6 & 0.7213 & 0.895 & 0.5581 & 0.6725 \\
Bex02 & 7 & 0.7214 & 0.794 & 0.2738 & 0.6766 \\
Bex03 & 5 & 0.7590 & 0.806 & 0.6353 & 0.7211 \\
Bex06 & 8 & 0.7922 & 0.905 & 0.6824 & 0.7601 \\
Bex12 & 5 & 0.6833 & 0.838 & 0.1667 & 0.6255 \\
Bex22 & 8 & 0.8260 & 0.777 & 0.4471 & 0.8030 \\
Bex27 & 6 & 0.8034 & 0.883 & 0.5422 & 0.7745 \\
Bex30 & 5 & 0.7880 & 0.812 & 0.3412 & 0.7540 \\
Bex32 & 6 & 0.7396 & 0.663 & 0.3176 & 0.6955 \\
Bex33 & 9 & 0.7709 & 0.913 & 0.4706 & 0.7383 \\
Bex37 & 5 & 0.7753 & 0.791 & 0.2907 & 0.7380 \\
Average & 6.36 & 0.7618 & 0.8252 & 0.4296 & 0.7235 \\
\hline
\end{tabular}

According to PCoA, the first three analyzed components explained $32.02 \%$ of variation across the samples $(16.69,8.91$, and $6.42 \%$ for the first, second, and third components, respectively). The projection of principal components based on genetic distance revealed a more compact grouping of individuals from population AGRO when compared with the clustering of individuals from population CAR, suggesting greater similarity between the individuals of population AGRO (Figure 1).

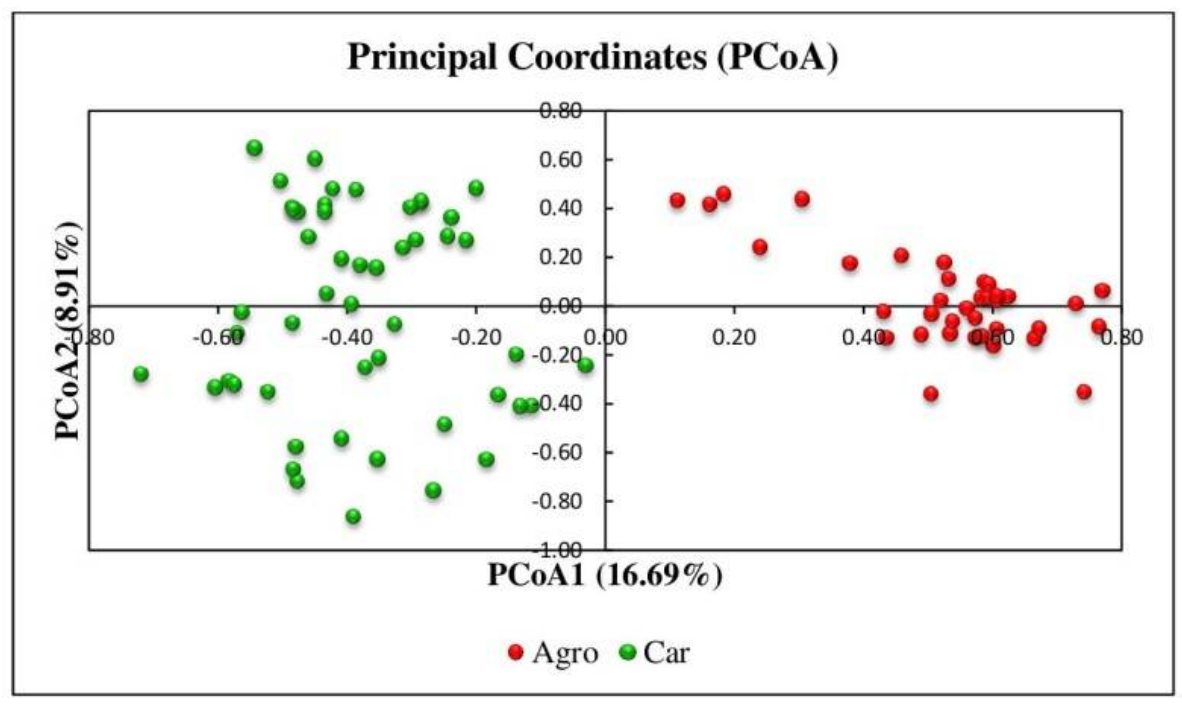

Figure 1. Scatterplot generated from the principal coordinate analysis of the 86 Brazil-nut individuals of the two populations sampled in Alta Floresta - MG, Brazil.

AMOVA showed that most part of the variability is within $(81 \%)$ rather than between $(19 \%)$ the evaluated populations (Table 2). 
Table 2. Analysis of molecular variance (AMOVA) of the two Bertholletia excelsa populations evaluated from 11 SSR markers.

\begin{tabular}{llllll}
\hline Source of variation & DF & SS & VC & TV (\%) & P-value \\
\hline Between populations & 1 & 80.648 & 0.900 & 19 & $<0.000$ \\
Within populations & 85 & 645.939 & 3.817 & 81 & \\
Total & 86 & 726.857 & 4.717 & & \\
\hline
\end{tabular}

Degrees of freedom (DF), sum of squares (SS), variance component (VC), total variance (TV) and P (Probabilities in 9999 random mutations). FST $=0.191$.

The dendrogram generated with all analyzed individuals based on Nei's distance (1973), by the UPGMA method, resulted in two groups formed (Figure 2). Group I (GI) was formed by the AGRO population individuals (individuals 1 to 36), while group II (GII) consisted of the CAR population individuals ( 37 to 86 ).

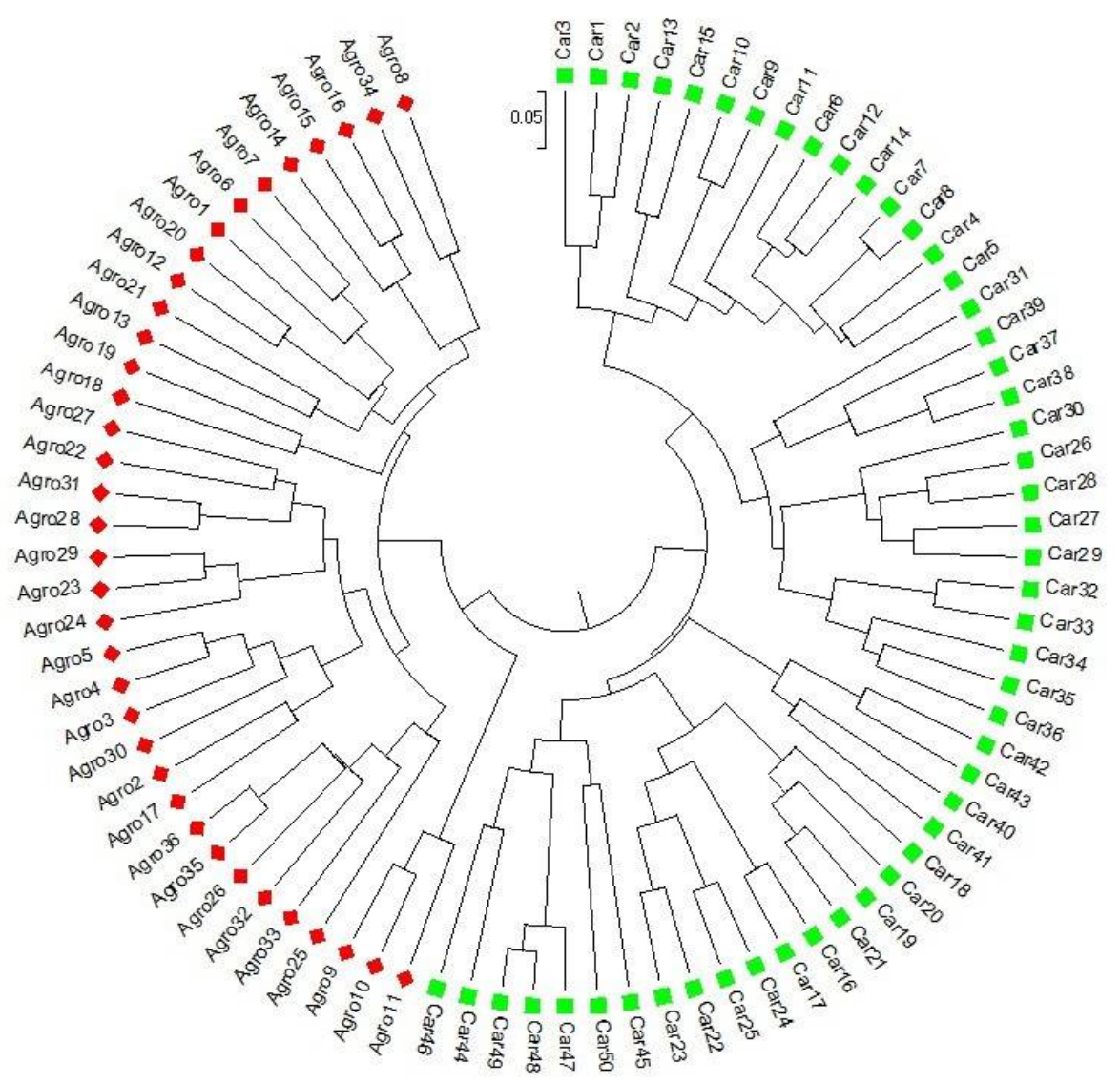

Figure 2. Dendrogram generated based on Nei's (1973) genetic distance, by the UPGMA method, of Bertholletia excels $a$ individuals of the two sampled populations. GI $=$ AGRO and GII $=$ CAR. 
The most suitable number of groups $(\mathrm{k})$ for the structuring of allele frequencies of the 86 individuals was four, as can be seen in Figure 3.

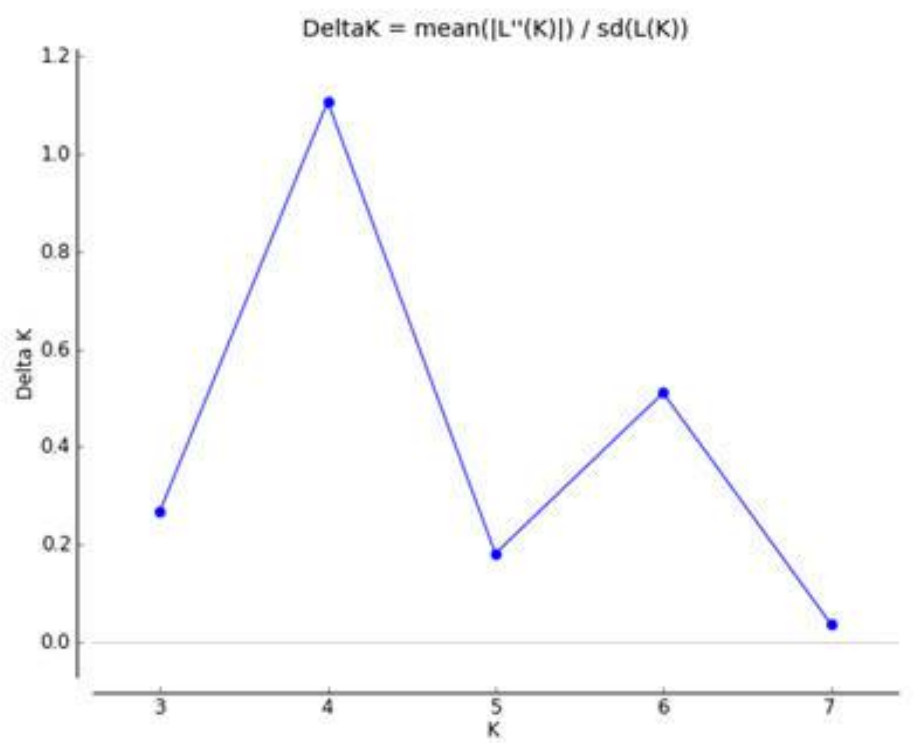

Figure 3. Graphic analysis of the ideal number of groups (K) of Bertholletia excelsa individuals according to the information from the 11 SSR loci, using the Structure Harvester resource.

In the clustering based on Bayesian inference (Structure software), all 36 individuals of the AGRO population were allocated in Group I, and the 50 individuals of population CAR were allocated in Groups II, III, and IV (Figure 4).

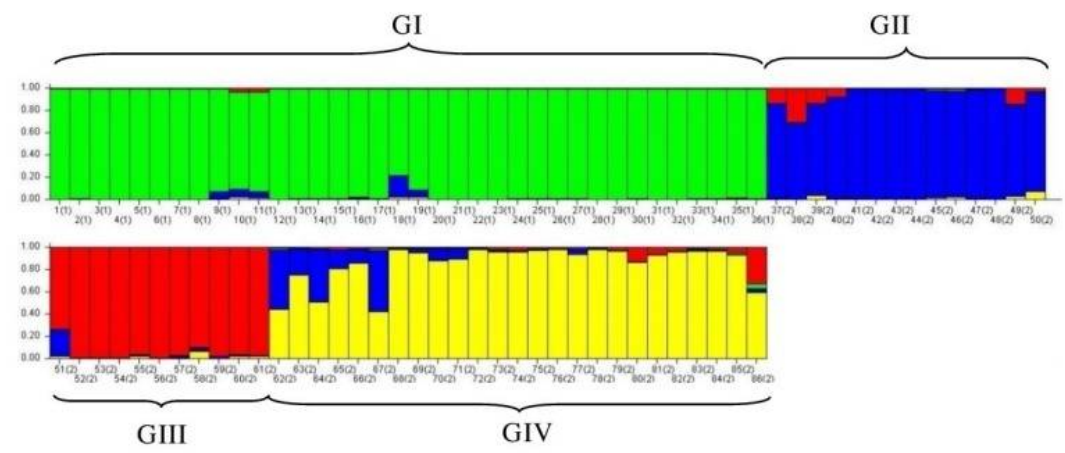

Figure 4. Representation of the distribution of the 86 Bertholletia excelsa individuals into groups according to molecular data of 11 SSR primers, using Structure software. The individuals are represented by vertical bars with colors according to the group where they belong (four groups, $K=4$ ).

\section{DISCUSSION}

The total number of alleles (70) and the average number of alleles per locus (6.36) found in this study were lower than those found by Reis et al. (2009), who optimized the 
same SSR loci for B. excelsa and obtained an average of 9.9 alleles per locus. However, Sujii et al. (2013) isolated and characterized seven microsatellite primers for B. excelsa and found a lower number of alleles per locus (average of five). Overall, the average number of alleles per locus found for $B$. excelsa agrees with the results found of other tree species using microsatellite markers. Silva et al. (2015) amplified an average of five alleles per locus in Theobroma speciosum and 6.69 in Theobroma subincanum. Guidugli et al. (2010) obtained an average of six alleles per locus in Cariniana legalis (Lecythidaceae), while Tambarussi et al. (2013) transferred microsatellite markers from Cariniana legalis to Cariniana estrellensis and found an average of 8.5 alleles per locus.

Molecular analyses provide elements to determine the origin, domestication and dispersal of native Amazonian crops in an archaeological context. Clement et al. (2010) affirmed that there is a pattern that includes the relation among species with incipiently or very recently domesticated populations, where there was a rapid pre- or post-conquest dispersal, anda lack of phylogeographic population structure, e.g. as found for guaraná (Paullinia cupana), cupuassu (Theobroma grandiflorum) and Brazil nut (B. excelsa).

All SSR markers used in this study were considered highly informative for the species, showing a PIC greater than 0.5. According to Botstein et al. (1980), markers with a PIC value below 0.25 are considered poorly informative; those revealing values between 0.25 and 0.5 are classified as moderately informative; and those with PIC values above 0.5 are considered highly informative.

The He and Ho values corroborate the results of Reis et al. (2009) for B. excelsa, in which the authors reported lower observed than expected heterozygosity in eight SSR loci (Bex02, Bex03, Bex12, Bex27, Bex30, Bex32, Bex33, and Bex37), with SSR locus Bex06 displaying the highest expected heterozygosity (0.950), as occurred in in this study. Contrasting results were found by Sujii et al. (2013) and Sujii et al. (2015), who used other microsatellite markers developed for B. excelsa and obtained He values lower than Ho values. According to Alves et al. (2007), most tropical tree species have shown a higher number of alleles per locus and consequently greater expected heterozygosity.

The highest level of diversity was seen within the populations, and this result is similar to that obtained by Sujii et al. (2015) in a study with nine populations of Brazil nut originating from the Amazon region, where $86.1 \%$ of the variation was found within the populations. Genetic studies performed from cpDNA sequences revealed little genetic diversity and no geographical structuring of within-population variability, thus suggesting a rapid and recent irradiation from an ancestral population (Shepard and Ramirez, 2011).

Kanashiro et al. (1997) estimated the variation within 100 individuals and among five provenances of $B$. excelsa by means 47 RAPD markers in Brazilian rain forests of the states of Pará and Acre. The screening product revealed that on average, $68.7 \%$ of the variation occurs within and only $31.3 \%$ of the observed variation was between provenances.

These findings confirm cross-pollination and self-incompatibility in the species, as reported in a previous study (Maués 2002). As stated by Hamrick and Godt (1989), crosspollinated species tend to present 10 to $20 \%$ of genetic variation between populations, and according to Sujii et al. (2015), self-incompatibility helps to maintain genetic diversity within populations. Buckley et al. (1988) estimated the genetic variation within and between two populations of Brazil-nut, from rain forests of Acre and Amazonas states, through enzymatic markers. They ndicated that much of the genetic diversity of this species can be preserved within one or a few populations. 
On this basis, Brazil nut's extinction threat is even more evident, despite the forbiddance of its felling as provided for by law, since the action of pollinizing agents of this species in fragmented forest environments, which are surrounded by pasture and agricultural-production matrices, is increasingly hampered.

The dendrogram generated by the UPGMA method showed that both populations were allocated in two distinct groups (Figure 2), and in the scatterplot of the 86 genotypes obtained by the Bayesian method, the two populations also diverged, although a higher number of groups was generated (Figure 4). This similarity pattern between geographically closer individuals possibly stems from behavior of pollinating bees. The main pollinators of Brazil-nut trees are bees of the genera Xylocuspoda and Eulaema (Maués, 2002; Santos and Absy, 2010), which can fly over distances greater than $20 \mathrm{~km}$ (Janzen, 1971). Although medium- and large-sized bees can visit several trees per day and overfly long distances, they normally graze in more restricted areas when there is abundance of flowered trees, which favors pollen dispersion in short distances (Janzen, 1971). Brazil nut is a social tree, as it forms agglomerates known as "castanhais", associated with other large-sized forest species (Salomão, 2009). Furthermore, this dispersion characteristic may influence the restricted foraging of pollinators, especially in the presence of barriers between populations, which might explain the population structure observed in the results (Figures 2 and Figure 4).

The dispersal of $B$. excelsa seeds is relatively restricted to tens of meters, originating from fruits that fall near the mother plant and also from the scattering promoted by animals (Haugaasen et al., 2010). In this way, these dispersal factors generate a spatial aggregation of related individuals. The dispersal traits help to understand the clustering pattern of individuals within the populations, especially for AGRO, whose individuals were more similar. Some researchers, in the face of observations of inefficient dispersal strategy of and discontinuous distribution of $B$. excelsa in the Amazon, have proposed the hypothesis that their origins are anthropogenic. Based on inconclusive evidence, other published studies from field observations and scientific research suggest that anthropogenic disturbance facilitates Brazil nut regeneration (Shepard and Ramirez, 2011).

The maintenance and continuity of genetic variability in $B$. excelsa are closely related to environmental degradation, which results from human activity, considering the reproductive and dispersive peculiarities of the species. Its reproduction can be compromised in case of fragmentation of its habitat, which hampers or even prevents gene flow through pollination, thereby lowering the pollination rate and consequently seed production. Buckley et al. (1988) emphasized that, although there is genetic conservation in only one or a few populations of $B$. excelsa, such populations must be very large because it appears that the large amount of genetic variation in Brazil nut populations is maintained by extensive gene flow and cross pollination over a large area.

By contrast, in areas where fruit production occurs appropriately, the presence of extractivism with intense seed harvest reduces the appearance (seed germination) of new individuals around the area, since, as declared by Tonini et al. (2008), areas under constant harvest of Brazil nut are characterized by the presence of few trees and few or even zero young individuals. Young individuals are commonly found in non-exploited forests or in forests with low harvest intensity (Peres et al., 2003). In the opinion of Sujii et al. (2015), some seeds must be left in the forest or seedlings must be planted therein to improve genetic diversity and ensure adequate amounts of seeds both for economic purposes and for the 
local maintenance of the species. Awareness is necessary to prevent fragmentations due to anthropic action and also inadequate extractivism from reducing the existing genetic variability in the natural populations of Brazil nut from the municipality of Alta Floresta MT, Brazil.

The subpopulations have genetic variability and do not present individuals genetically identical or very close to each other. Therefore, these subpopulations can be a source of divergent genotypes for the implementation of in situ germplasm banks and also for the implementation of programs for the propagation and conservation of the species.

\section{ACKNOWLEDGMENTS}

The authors thank the Coordenação de Aperfeiçoamento de Pessoal de Nível Superior (CAPES) and Fundação de Amparo à Pesquisa do Estado de Mato Grosso (FAPEMAT) for financial support.

\section{REFERENCES}

Aguilar FJ, Mills JP, Delgado J, Aguilar MA, et al. (2010). Modelling vertical error in LiDAR-derived digital elevation models. ISPRS J. Photogramm. Remote Sens. 65: 103-110.

Albuquerque TCS, Evangelista TC and Albuquerque Neto AAR (2015). Níveis de sombreamento no crescimento de mudas de castanheira do Brasil. Agroambiente. 9: 440-445.

Alves RM, Sebbenn AM, Artero AS, Clement C, et al. (2007). High levels of genetic divergence and inbreeding in populations of cupuassu (Theobroma grandiflorum). Tree Genet. Genomes. 3: 289-298.

Arbeláez-Cortes E, Castillo-Cárdenas MF, Toro-Perea N and Cárdenas-Henao H (2007). Genetic estructure of the red mangrove (Rhyzophora mangle L.) on the Colombian Pacific detected by microsatellite molecular markers. Hydrobiologia. 583: 321-330.

Blouin MS, Parsons M, Lacaille V and Lotz S (1996). Use of microsatellites to classify individuals by relatedness. Mol. Ecol. 5: 393-401.

Botstein D, White RL and Skolmick H (1980). Construction of a genetic linkage map in man using restriction fragment lenght polymorphisn. Am. J. Hum. Genet. 32: 314-331.

Buckley DP, O'malley DM, Apsit V, Prance GT, et al. (1988). Genetics of Brazil nut (Bertholletia excelsa Humb. \& Bonpl.: Lecythidaceae). Theoret. Appl. Genet. 76: 923-928.

Caixeta ET, Ferrão LFV and Zambolim EM (2013). Marcadores moleculares. In: Biotecnologia aplicada ao melhoramento de plantas (Borém A, Fritische-Neto R, eds.). Universidade Federal de Viçosa, Viçosa, Minas Gerais, p. 31-68.

Clement C, Cristo-Araújo D, D'Eeckenbrugge GC, Pereira AA, et al. (2010). Origin and domestication of native Amazonian crops. Diversity. 2: 72-106.

Costa JR, Castro ABC, Wandelli EV, Coral SCT, et al. (2009). Aspectos silviculturais da castanha-do-brasil (Bertholletia excelsa) em sistemas agroflorestais na Amazônia Central. Acta Amazon. 39(4): 843-850.

Cunha ESM and Dantas FLCG (1997). O que você precisa saber sobre a castanha-do-brasil: de informações técnicas a curiosidades. Macapá: SEMA, 93 p.

Dardengo JFE, Rossi AAB, Silva BM, Silva IV, et al. (2016). Diversity and spatial genetic structure of a natural population of Theobroma speciosum (Malvaceae) in the Brazilian Amazon. Rev. Biol. Trop. 64(3): 1091-1099.

Doyle JJ and Doyle JL (1990). Isolation of plant DNA from fresh tissue. Focus. 12: 39-40.

Earl DA and Vonholdt BM (2012). Structure Harvester: a website and program for visualizing Structure output and implementing the Evanno method. Conservation Genet. Resour. 4: 359-361.

Evanno G, Regnaut S and Goud J (2005). Detecting the number of clusters of individuals using the software STRUCTURE: a simulation study. Mol. Ecol. 14: 2611-2620.

Guidugli MC, Accoroni KAG, Mestriner MA, Contel EPB, et al. (2010). Genetic characterization of 12 heterologous microsatellite markers for the giant tropical tree Cariniana legalis (Lecythidaceae). Genet. Mol. Biol. 33: 131-134.

Hamrick JL and Godt JW (1989). Allozyme diversity in plant species. In: Plant population genetics, breeding, and genetic resources (Brown AHD, Clegg MT, Kahler AL, eds.). Sunderland, Sinauer Associates, 43-63.

Haugaasen JM, Haugaasen T, Peres CA, Gribel R, et al. (2010). Seed dispersal of the Brazil nut tree (Bertholletia excelsa) by scatter-hoarding rodents in a central Amazonian forest. J. Trop. Ecol. 26: 251-262.

IUCN (2017). The IUCN Red List of Threatened Species. Version 2017-3. Available at [http://www.iucnredlist.org]. 
Isagi Y, Kanazashi T, Suzuki W, Tanaka H, et al. (2004). Pollination patterns in Magnolia obovata revealed by microsatellite paternity analysis. Int. J. Plant Sci. 165: 1047-1053.

Janzen DH (1971). Seed predation by animals. Ann. Rev. Ecol. and Syst. 2: 465-492.

Kageyama PY, Sebbenn AM, Ribas LA, Gandara FB, et al. (2003). Diversidade genética em espécies tropicais de diferentes estágios sucessionais por marcadores genéticos. Sci. For. 64: 93-107.

Kamada T, Picoli EAT, Alfenas AC, Cruz CD, et al. (2009). Diversidade genética de populações naturais de Pfaffia glomerata (Spreng.) Pedersen estimada por marcadores RAPD. Acta Sci. Agron. 31: 403-409.

Kanashiro M, Harris SA and Simons A (1997). RAPD diversity in Brazil nut (Bertholletia excelsa Humb. and Bonpl., Lecythidaceae). Silvae Genet. 46: 219-223.

Kumar S, Tamura K and Nei M (2004). MEGA3: Integrated software for Molecular Evolutionary Genetics Analysis and sequence alignment. Brief. Bioinform. 5: 150-163.

Liu K and Mouse S (2005). PowerMarker: Integrated analysis environment for genetic marker data. Bioinformatics. 21: $2128-2129$.

Maués MM (2002). Reproductive phenology and pollination of the brazil nut tree (Bertholletia excelsa Humb. e Bonpl. Lecythidaceae) in Eastern Amazonia. In: The conservation Link Between Agriculture and Nature Pollinating Bees (Kevan P, Imperatriz-Fonseca VL, eds.). Ministério do Meio Ambiente, Brasília, Distrito Federal, p.245-254.

Nei M, Tajima F and Tateno Y (1983). Accuracy of estimated phylogenetic trees from molecular data. J. Mol. Evol. 19: 153-170.

Peakall R and Smouse PE (2012). GenAlEx 6.5: genetic analysis in Excel. Population genetic software for teaching and research-an update. Bioinformatics. 28: 2537-2539.

Peres CA, Baider C, Zuidema PA, Wadt LHO, et al. (2003). Demographic threats to the sustainability of Brazil-nut exploitation. Science. 302: 12-14.

Pritchard J, Stephens M and Donnelly P (2000). Inference of population structure using multilocus genotype data. Genetics. 155: 945-959.

Pritchard JK and Wen W (2004). Documentation for structure software: Version 2.1. Available at (http://www.pritch.bsd.uchicago.edu).

Rafalski JA, Vogel JM, Morgante M and Powell W (1996). Generating and using DNA markers in plants. In: Non Mammalian Genomic Analysis: a Practical Guide (Birren B, Lai E, eds.). Academic Press. 12: 75-134.

Reis AMM, Braga AC, Lemes MR, Gribel R, et al. (2009). Development and characterization of microsatellite markers for the Brazil-nut tree Bertholletia excelsa Humb. e Bonpl. (Lecythidaceae). Mol. Ecol. Resour. 9: 920-923.

Rivas LH, Giustina LD, Luz LN, Karsburg IV, et al. (2013). Genetic diversity in natural populations of Theobroma subincanum Mart. in the Brazilian Amazon. Genet. Mol. Res. 12: 4998-5006.

Rossi AAB, Oliveira LO, Venturini BA and Silva RS (2009). Genetic diversity and geographic differentiation of disjunct Atlantic and Amazonian populations of Psychotria ipecacuanha (Rubiaceae). Genetics. 136: 57-67.

Saha MC, Cooper JD, Rouf Mian MA, Chekhovskiy K, et al. (2006). Tall fescue genomic SSR markers: development and transferability across multiple grass species. Theor. Appl. Genet.. 113: 1449-1458.

Salomão RP (2009). Densidade, estrutura e distribuição espacial da castanheira-do-brasil (Bertholletia excelsa H. e B.) em dois platôs de floresta ombrófila densa na Amazônia setentrional brasileira. Boletim do Museu Paraense Emilio Goeldi: Ciências Naturais. 4: 11-25.

Santos CF and Absy ML (2010). Polinizadores de Bertholletia excelsa (Lecythidales: Lecythidaceae): Interações com Abelhas sem Ferrão (Apidae: Meliponini) e Nicho Trófico. Neotrop. Entomol. 39: 854-861.

Sebbenn AM, Carvalho ACM, Freitas MLM, Moraes SMB, et al. (2010). Low levels of realized seed and pollen gene flow and strong spatial genetic structure in a small, isolated and fragmented population of the tropical tree Copaifera langsdorffii Desf. Heredity. 106: 134-145.

Selkoe KA and Toonen RJ (2006). Microsatellites for ecologists: a practical guide to using and evaluating microsatellite markers. Ecol. Lett. 9: 615-629.

Shepard GH and Ramirez H (2011). "Made in Brazil": human dispersal of the Brazil nut (Bertholletia excelsa, Lecythidaceae) in ancient Amazonia. Econ. Bot. 65: 44-65.

Silva BM, Rossi AAB, Dardengo JFE, Silva CR, et al. (2015). Genetic structure of natural populations of Theobroma in the Juruena National Park, Mato Grosso State, Brazil. Genet. Mol. Res. 14: 10365-10375.

Souza IF (2006). Production chain of Brazil-nut (Bertholletia excelsa) in the State of Mato Grosso. Master's thesis. Universidade Federal de Mato Grosso do Sul, Campo Grande, Mato Grosso do Sul. 152p. Available at [http://repositorio.cbc.ufms.br:8080/jspui/bitstream/123456789/880/1/Ivonete\%20Fernandes\%20de\%20Souza.pdf]

Sujii OS, Martins K, Wadt LHO, Azevedo VCR, et al. (2015). Genetic structure of Bertholletia excelsa populations from the Amazon at different spatial scales. Conserv. Genet. 16: 955-964.

Sujii OS, Inglis PW, Ciampi AY, Solferini VN, et al. (2013). Isolation and characterization of microsatellite markers for Bertholletia excelsa (Lecythidaceae) population genetic analysis. Genet. Mol. Res. 12: 5278-5282.

Tambarussi EV, Sebbenn AM, Moreno MA, Ferraz EM, et al. (2013). Microsatellite markers for Cariniana legalis (Lecythidaceae) and their transferability to C. estrellensis. Appl. Plant Sci. 1(6): 1200493.

Tonini H, Costa P and Kaminski PE. (2008). Estrutura e produção de duas populações nativas de castanheira-do-brasil (Bertholletia excelsa O. Berg) em Roraima. Floresta. 38: 445-457. 
Yanaka FY, Dall'Agnol M, Schifino-Wittmann MT, Dias PMB, et al. (2005). Variabilidade genética em populações naturais de Bromus auleticus Tris. ex Ness (Poaceae) com base em isoenzimas e marcadores RAPD. Rev. Bras. Zootec. 34: 1897-1904. 